The preparations were cultured for lactobacilli on MRS agar (Unipath, Basingstoke, Hampshire), for enterococci on $\mathrm{m}$-enterococcus agar (Difco, East Molesey, Surrey), and for anaerobes on Columbia agar (Unipath) plus 5\% whole horse blood. Either one whole tablet was crushed in a sterile mortar or the content of a capsule (opened under aseptic conditions) or a weighed amount of powder (approximately $500 \mathrm{mg}$ ) was suspended in $10 \mathrm{ml}$ of MRS broth, blended with a Vortex mixer for 1 minute, and allowed to stand for 30 minutes; viable counts were made from the supernatant fractions. Plates were incubated for 48 hours at $37^{\prime \prime} \mathrm{C}$. As many colony types as possible on each medium were counted and identified with $50 \mathrm{CH}$, API Strep 20, and API rapid ID $32 \mathrm{~A}$ kits (bio-Mérieux, Basingstoke, Hampshire), as indicated.

Only two products (B and $H$ ) matched their labelled microbiological specifications qualitatively and quantitatively (table). The 11 other brands did not contain $L$ acidophilus, contained extra species, or lacked a listed species, or numbers were less than a tenth of those stated. Four brands (C, E, $\mathrm{G}$, and $\mathrm{K}$ ) contained bacterial species not stated on the label (Enterococcus faecium in two, Pediococcus pentosaceus in two). Five brands (A, F, J, K, and L) did not contain the listed $L$ bifidus (which was reclassified as a Bifidobacterium $\mathrm{sp}$ (an obligate anaerobe) more than 20 years ago. ${ }^{3}$ Oral probiotics may be beneficial in certain specific conditions-for example, Saccharomyces boulardii or $B$ bifidum plus Streptococcus thermophilus in diarrhoea. ${ }^{45}$ But claims made on the labels of some of the products tested here- "maintains a healthy digestion," "improves digestibility and assimilation of food," "keeping the intestinal contents sweet," "assist . . . general well-being," "protects skin . . . against harmful microbes," "build immunity"-are not supported. The British National Formulary states that "lactobacillus preparations are valueless" in acute gastrointestina infections.

In conclusion, the public and health professionals should be aware that the labelling of some probiotics may be misleading, in terms of both the microbiological content and possible beneficial effects.

J M T HAMILTON-MILLER

Professo

SAROJ SHAH

Senior medical laboratory scientific officer CRAIG T SMITH

Technicia

Department of Medical Microbiology,

Royal Free Hospital School of Medicine,

London NW3 2QG

1 Fuller R, ed. Probiotics-the scientific basis. London: Chapman and Hall, 1992.

Gilliland SE, Speck ML. Enumeration and identity of lactobacill in dietary products. Fournal of Food Protection 1977;40:760-2.

3 Buchanan RE, Gibbons NE, eds. Bergey's manual of determinative bacteriology. (8th ed). Baltimore: Williams and Wilkins, 1974: 577.

4 Saavedra JM, Bauman NA, Oung I, Perman JA, Yolken RH Feeding of Bifidobacterium bifidum and Streptococcus thermophilus to infants in hospital for prevention of diarrhoea thermophilus to infants in hospital for prevention

5 McFarland LV, Surawicz CM, Greenberg RN, Elmer GW, Moyer KA, Melcher SA, et al. Prevention of $\beta$-lactamMoyer KA, Melcher SA, et al. Prevention of $\beta$-lactam-
associated diarrhea by Saccharomyces boulardii compared associated diarrhea by Saccharomyces boulardin
with placebo. Am f Gastroenterol 1995;90:439-48.

\section{Deaths in police custody}

EdrToR,-During the past 12 months 15 deaths have occurred in police custody in Britain, according to the national police authorities. Forensic investigation has comprised at least a postmortem examination in all cases, and in only one case is prosecution of the police officer concerned pending. It therefore seems that in some circumstances a pathological entity exists that predisposes subjects in police custody to certain forms of natural death. Underlying cardiomyopathies, cardiac valve lesions, and cardiac conduction defects have all been mooted as causes of death. Among potential hypotheses to explain this phenomenon are supranormal secretion of catecholamines and supranormal surges in blood pressure due to the psychological and physical stress of police custody.

I believe that a prospective confidential inquiry into the cause of deaths in police custody should be set up. It is imperative that the BMA is not perceived by the public to be in complicity with the police authorities on this issue. The effect of such a perception on the South African Medical Association in the 1980 s was all too evident. We need to ascertain and document the cause of death in all cases. Such an inquiry could serve to identify a hitherto unknown clinical syndrome and allow preventive measures to be taken against deaths in police custody.

VINOD PATEL Consultant physician

George Eliot NHS Trust, (diabetes and endocrinology)

Nuneaton,

Warwickshire CV10 7DJ

\section{Patients taking stable doses of morphine may drive}

EDITOR,-A guide for medical practitioners published by the Medical Commission on Accident Prevention, Medical Aspects of Fitness to Drive, has been widely distributed within the medical profession. ${ }^{1}$ In a section on drugs acting on the central nervous system it states that "the more powerful narcotic analgesics such as morphine produced marked sedation and patients requiring them should not drive." This has important implications for the quality of life of patients receiving palliative care who require regular doses of morphine to control pain

Experience in palliative care indicates that the symptoms that occur at the start of treatment with morphine generally resolve within a few days of the dose being stabilised. It is commonly believed, therefore, that patients taking a stable dose may drive without hazard to themselves or other road users. There are, however, few objective data confirming this belief.

Vainio et al have recently reported the results of psychological and neurological tests designed for professional drivers of motor vehicles that were conducted in two groups of patients with cancer. Twenty four of the patients were taking slow release morphine orally at regular intervals to control cancer pain, and 25 were free of pain without taking regular analgesics. The mean daily dose in the treated patients was $209 \mathrm{mg}$ (range $60-1100 \mathrm{mg}$ ) and had been stable for at least two weeks. The results showed that long term, stable, treatment with morphine at these doses had only a slight and selective effect on functions related to driving and that this effect would not be hazardous in traffic. Hanks, commenting on these findings, suggested reasons why long term morphine for pain should not result in the same degree of sedation that results from single doses in people who do not take opioids regularly.

These findings support the impression of most palliative care physicians that driving need not be 
automatically contraindicated in patients whose pain is controlled with stable doses of morphine. It is obviously wise, however, to discourage driving when morphine is started or when the dose is increased in response to worsening pain.

St Christopher's Hospice,

Director of studies

London SE26 6DZ

1 Beeley L. Drugs and medicines. In: Medical aspects of fitness to drive; a guide for medical practitioners. Medical Commission on Accident Prevention, 1995

2 Vainio A, Ollila J, Matikainen E, Rosenberg P, Kalso E. Driving ability in cancer patients receiving long-term morphine analgesia. Lancet 1995;346:667-70.

3 Hanks GW. Morphine sans Morpheus. Lancet 1995;346:652-3.

\section{Patients with hydrocephalus should have regular eye checks}

EdIToR,-Pat Tomlinson and I D Sugarman's paper is a reminder that patients with shunts for hydrocephalus may suffer complications at any age. ${ }^{1}$ Ophthalmic complications are not specifically mentioned in their paper but are common and neglected. ${ }^{23}$ I recently saw a 15 year old patient who had been blinded as a result of such complications. Ophthalmic symptoms such as blurred vision and diplopia should be investigated promptly. Eye signs such as papilloedema and motility disorders may be the only objective clinical evidence of dysfunction of the shunt. Regular eye examinations from birth or diagnosis throughout life are as necessary in hydrocephalus as in diabetes or prematurity. I hope that all those who care for patients with hydrocephalus will review their practice.

Eye Unit,

Southampton General Hospital

Southampton SO16 6YD

1 Tomlinson P, Sugarman ID. Complications with shunts in adults with spina bifida. $B M 7$ 1995;311:286-7. (29 July.)

2 Gaston H. Does the spina bifida clinic need an ophthalmologist? Zeitschrift für kinderchirurgie und Grenzgebiete 1985;40 Zeitschrift für

3 Gaston H. Ophthalmic complications of spina bifida and hydrocephalus. Eye 1991;5:279-90.

\section{Torture and war}

\section{Medical associations should try to stop torture in Israel}

EDrToR,-Derek Summerfield is too mild in his criticism of the Israeli Medical Association. ${ }^{1}$ Several undisputed facts do not permit silence on this issue by a member of the World Medical Association.

Torture is practised in Israel and is sanctioned by the state. The Landau Commission, set up by the Israeli government in 1987, allowed security personnel to use "non-violent psychological pressure and vigorous and continuous interrogation and a moderate degree of physical pressure" in the interrogation of suspects. Exactly which methods were permissible appeared in an annex of the commission's report, which was never made public. In November 1994 a cabinet committee suggested that even these restrictions on torture could be relaxed. The Human Rights Watch report from which Summerfield quotes describes in detail the methods used: "Chief methods include use of prolonged sleep deprivation, use of blindfolds, tight-fitting hoods, shackling or otherwise forcing detainees into body positions that grow increasingly painful, prolonged toilet and hygiene deprivation and verbal threats and insults. Many but not all are also beaten during rounds of questioning."2 Several other reports including two from an Israeli human rights group, ${ }^{34}$ confirm such practices.
I am certain that, were there such evidence of torture in Britain, the BMA would feel an obligation to speak out. Not to do so would leave the profession morally bankrupt. However, Israel doctors are implicated not only by their silence: according to Human Rights Watch, doctor regularly carry out rounds in Israeli prisons and detention centres, and some do not documen evidence of torture after examining and treating patients.

The World Medical Association did not tolerate torture in South Africa and should not tolerate i in Israel. A country that increasingly plays an important part in the Western medical community officially sanctions torture, and its doctors at bes observe in silence the results of such torture and at worst permit continued torture of individua detainees. Not only can the Israeli Medical Association no longer remain silent, but the World Medical Association and the BMA should endeavour to ensure that this cruelty is stopped.

N MAMODE

Overton Road

Registrar in vascular surger

Overton Road,
Kilmarnock KA2 ODN

1 Summerfield D. Israeli Medical Association shirks "political aspects" of torture. $B M F$ 1995;311:755. (16 September.)

2 Human Rights Watch. Torture and ill-treatment. Israel's interrogation of Palestinians from the occupied territories. New York: HRW, 1994.

3 Israeli Information Centre for Human Rights in the Occupied Territories. The interrogation of Palestinians in the intifada. B'tselem: IICHROT, 1991.

4 Israeli Information Centre of Human Rights in the Occupied Territories. Torture during interrogation. B'tselem: IICHROT, 1994.

\section{International congresses held in Israel should be boycotted}

EDIToR,-Derek Summerfield makes a valid point regarding doctors' complicity with torture in Israel. ${ }^{\prime}$ Israeli law permits torture under the Landau Commission but limits its degree, in theory. One way of affecting the Israeli Medical Association would be for doctors to boycott the many international congresses held in Israel until the association ensures its members' adherence to international codes against torture.

Frenchay Hospital,

CHRIS BURNS-COX Bristol BS16 1LR

1 Summerfield D. Raising the dead: war, reparation, and the politics of memory. BMf 1995;311:495-7. (19 August.)

\section{Letter did not mention terrorists' activities} in Israel

EDITOR,-Derek Summerfield perverts the issue in labelling the Israeli Medical Association as the guilty party with regard to torture in Israel. ${ }^{1} \mathrm{His}$ letter makes no mention of the acts of terrorists. Israel is at war with terrorists that surround her and infiltrate to the centre of daily life. The terrorists choose sites such as a high street, bus station, or junction, where they can cause the maximum loss of life to Jews, Arabs, or tourists indiscriminately. (In the last words of Itzak Rabin "we are at war to make peace.")

What service is Summerfield doing by labelling the Israeli Medical Association the guilty party when the perpetrators of the outrage to human rights are the terrorists? In which journal does the Medical Foundation for the Care of Victims of Torture malign the terrorists? In which journal does that organisation proclaim loudly the rights of the innocent victims of terrorists? What is the purpose of aligned political comment in a medical journal?

PO Box 863,

JEREMY RAPHAEL

General practitioner

Metar
1 Summerfield D. Israeli Medical Association shirks "political aspects" of torture. $B M F$ 1995;311:755. (16 September.)

\section{Nicaragua has been neglected by Western media}

EDrToR,-Derek Summerfield writes of "horrific attacks" experienced by Nicaraguan peasants at the hands of the Contra guerrillas, who were "sponsored by the United States." He also writes of American foreign policy, which "declared the war in Nicaragua, whose hallmark was atrocity." It is estimated that this war left 12000 people dead, 15000 wounded, and 3000 homeless.

How is it that Ronald Reagan, who led the United States during all of this, is considered to have been a great leader, informed by Christian values and dedicated to freedom and democracy all over the world? If the above statements are true then his leadership was hypocritical and evil, and the tragedy in Nicaragua, similar to that in the former Yugoslavia, has been shamefully neglected by other world leaders and the Western media generally.

B O'BRIEN

London N18 2ER

General practitioner

1 Summerfield D. Raising the dead: war, reparation, and the politics of memory. BMF 1995;311:495-7. (19 August.)

2 Chomsky N. Turning the tide. London: Pluto Press, 1995:14.

\section{Article omitted to mention victims of left wing revolutionary politics}

EDITOR,-Derek Summerfield's account of the tragic way in which the victims of political mass murder are conveniently forgotten is an importan document rendered fascinating by the fact that all the villains of the past 80 years whom he mentions were right wing and mostly Western or backed by the West. ${ }^{1}$ He lists 14. However, the millions of victims of those inspired by left wing revolutionary politics (for example, those killed in the former Soviet Union; by the Khmer Rouge; and, closer to home, by the Irish Republican Army) are not mentioned at all.

This forgetfulness is so much in the current liberal intellectual tradition, and it is so incorrect to point it out, that I hesitated to put pen to paper; but, having reread Summerfield's stirring words ("This denial, and the impunity of those who maintain it, must be challenged if survivors are to make sense of their losses and the social fabric is to mend"), I decided that I should. I look forward to a further article about the data-or, rather, the people-omitted.

DEREK STEINBERG

14 Devonshire Place, Consultant psychiatrist 14 Devonshire Place,

1 Summerfield D. Raising the dead: war, reparation, and the politics of memory. $B M \mathcal{F}$ 1995;311:495-7. (19 August.)

\section{Atrocities in eastern Europe were not mentioned}

EDIToR,-Derek Summerfield concludes that "The struggle is to get the social order to own up to what is done to reduce human beings to dust, albeit loved dust, and to the uncounted others who are not even that, merely names in the mouths of those who remember. This is a struggle without end but one that cannot be shirked." But terror seized me when I realised that Summerfield has a devastating political blind side. His article makes no mention of the atrocities perpetrated by the Leninist and Stalinist communists of the 20th century in Lithuania, Latvia, Estonia, and other parts "of eastern Europe. So he too has the capacity to deny the undeniable. The editors of a factual, objective 